\title{
Dramaturgi Relasi Dokter dan Pasien di Rumah Sakit Daerah Dr. Zainoel Abidin Banda Aceh
}

\author{
Dara Hersavira*) \\ Magister Ilmu Komunikasi Universitas Muhammadiyah Sumatera Utara, Indonesia \\ Koresponden: Darasavira@gmail.com
}

\begin{abstract}
Abstrak
Penelitian ini menggunakan metode dengan pendekatan kualitatif-deskriptif. Tujuan penelitian untuk menganalisis panggung atau wilayah depan (front region) dan belakang (back region) pada teori dramaturgi relasi antara dokter dan pasien di RSUD dr. Zainoel Abidin, Banda Aceh, Provinsi Aceh. Informan penelitian berasal dari enam dokter spesialis dan tiga pasien di RSUD dr. Zainoel Abidin, Banda Aceh, Provinsi Aceh. Berdasarkan hasil penelitian diketahui bahwa pengelolaan kesan (impression management) merupakan kunci dari terjadinya proses panggung depan dan panggung belakang. Secara keseluruhan, pemetaan panggung depan para informan hampir sama semuanya. Di panggung depan para informan menunjukkan komponenkomponen panggung depan merupakan pengelolaan kesan dalam usaha menampilkan citra diri dengan komponen busana, sikap, dan latar panggung depan. Penampilan (appearance) dan sikap (manner) yang ditampilkan oleh seorang dokter di panggung depan dibentuk sesuai citra yang ingin mereka tampilkan.
\end{abstract}

Kata kunci:Dramaturgi, Relasi Dokter dan Pasien

\begin{abstract}
This research uses a method with a qualitative-descriptive approach. The purpose of the study was to analyze the stage or front region and back region on the theory of dramaturgy relations between doctors and patients in RSUD dr. Zainoel Abidin, Banda Aceh, Aceh Province. The research informants were from six specialist doctors and three patients at the RSUD dr. Zainoel Abidin, Banda Aceh, Aceh Province. Based on the results of the study note that impression management is the key to the process of the front stage and back stage. Overall, mapping the front stage of the informants was almost the same. On the front stage, the informants showed that the components of the front stage were the management of impressions in an effort to present their self-image with the components of clothing, attitudes, and setting of the front stage. The appearance and manner displayed by a doctor on the front stage is shaped according to the image they want to display.
\end{abstract}

Keywords: Dramaturgi, Doctor and Patient Relations

\section{Pendahuluan}

Rumah Sakit Umum Daerah (RSUD) dr. Zainoel Abidin Kota Banda Aceh, merupakan rumah sakit rujukan tertinggi atau rumah sakit pusat daerah di Provinsi Aceh. Setiap harinya, melayani \pm 2000 orang pasien yang dirujuk dari seluruh kabupaten atau kota yang ada di Aceh. Idealnya Rumah Sakit Pemerintah Aceh ini hanya dapat menampung 1.200 orang saja untuk pelayanan medis setiap harinya, namun dikarenakan angka pasien semakin hari semakin bertambah. Untuk itu rumah sakit harus mampu memberikan pelayanan yang ekstra.

Pelayanan medis untuk berkonsultasi dengan dokter spesialis pun sangat terbatasi, satu pasien hanya dapat berkonsultasi 5 sampai 10 menit saja. Dokter spesialis tetap dituntut oleh rumah sakit untuk memberikan pelayanan sesuai dengan visi dan misi dari RSUD dr. Zainoel Abidin itu sendiri. Salah satunya adalah cara dokter berkomunikasi dengan setiap pasiennya. Komunikasi yang efektif antara dokter dan pasien merupakan salah satu kompetensi yang sangat penting dan harus dikuasai oleh dokter. Kompetensi komunikasi menentukan keberhasilan dalam membantu penyelesaian masalah kesehatan pasien. Komunikasi yang efektif dapat mengurangi keraguan pasien, serta menambah kepatuhan dari pasien. Dokter dan pasien sama-sama memperoleh manfaat 
dari saling berbagi dalam hubungan yang erat. Setiap pihak merasa dimengerti. Pasien merasa aman dan terlindungi jika dokter yang menanganinya melakukan yang terbaik untuk pasiennya. Ketika saling terhubung, sang dokter dapat mengerti dan bereaksi lebih baik pada perubahan perilaku dan perhatiannya pada pasien setiap saat. Komunikasi yang efektif antara dokter dan pasien sangatlah diperlukan untuk memperoleh hasil yang optimal, berupa masalah kesehatan yang dapat diselesaikan dan kesembuhan pasien. (Rusmana, 2009; Hardjodisastro, 2010). Komunikasi kesehatan antara dokter dan pasien adalah proses komunikasi yang melibatkan pesan kesehatan, unsur-unsur atau peserta komunikasi. Komunikasi yang dibangun dengan baik antara dokter dan pasien merupakan salah satu kunci keberhasilan dokter dalam memberikan upaya pelayanan medis. Sebaliknya, ketidakberhasilan dokter terhadap masalah medis, jika dikomunikasikan dengan baik tidak akan menimbulkan perselisihan. Komunikasi dokter dan pasien sebagai bentuk perilaku yang terjadi dalam berkomunikasi yaitu bagaimana pelaku (dokter dan pasien) mengelolah dan mentransformasikan dan pertukaran suatu pesan (Rogers, 2006:15). Dalam proses pertukaran pesan komunikasi antara dokter dan pasien merupakan salah satu faktor penentu keberhasilan proses komunikasi itu sendiri.

Kemampuan seorang dokter untuk memiliki keterampilan berkomunikasi dengan baik terhadap pasiennya untuk mencapai sejumlah tujuan yang berbeda. Menurut Ong, dkk (1995) yang dikutip oleh Dianne Berry, (2007: 28 ) mengemukakan bahwa ada 3 (tiga) tujuan yang berbeda komunikasi antara dokter dan pasien, yaitu : (1) menciptakan hubungan interpersonal yang baik (creating a good interpersonal relationship), (2) pertukaran informasi (exchange of information), dan (3) pengambilan keputusan medis (medical decision making). Mengendalikan komunikasi antara dokter dan pasien membutuhkan interaksi yang baik, sehingga membuat komunikasi sampai tanpa tidak adanya kesalahpahaman antar kedua belah pihak.

Dokter adalah orang penting (the significant person) bagi individu-individu yang mengharapkan kesembuhan atas penyakitnya dan juga bagi mereka yang berupaya memelihara kesehatannya. Dalam memberikan layanan terhadap pasien, dokter melakukan hubungan secara fungsional dan emosional. Profesi dokter, merupakan sebuah profesi elite yang sangat terpadang di masyarakat mana pun. Tak heran, banyak pula orang tua yang mengharapkan anak mereka menjadi seorang dokter, namun tak bisa dipungkiri juga bahwa seorang dokter juga hanyalah manusia biasa, yang memiliki kehidupan lepas di luar profesinya sebagai seorang dokter.

Proses interaksi, diawali dengan pengelolaan kesan yang baik atau sering disebut dengan pengelolaan kesan (Impression Management). Pengelolaan kesan adalah suatu bentuk dari upaya presentasi diri. Sering kali orang-orang melakukan pengelolaan kesan tanpa sadar, ada kalanya setengah sadar, namun juga dengan penuh kesadaran demi kepentingan pribadi, finansial, sosial dan politik tertentu (Mulyana, 2003:120). Presentasi diri merupakan upaya individu untuk menumbuhkan kesan tertentu di depan orang lain dengan cara menata perilaku agar orang lain memaknai identitas dirinya sesuai dengan apa yang ia inginkan. Dalam proses produksi identitas tersebut, ada suatu pertimbangan-pertimbangan yang dilakukan mengenai atribut simbol yang hendak digunakan sesuai dan mampu mendukung identitas yang ditampilkan secara menyeluruh.

Menurut Goffman (1959) pengelolaan kesan dibutuhkan ketika kesulitan persepsi timbul karena personal stimulus berusaha menampilkan petunjuk-petunjuk tertentu untuk menimbulkan kesan tertentu pada diri penanggap (Jalaluddin, 2007 : 96). Orang lain menilai berdasarkan petunjuk petunjuk yang pribadi berikan, dan dari penilaian itu mereka memperlakukan pribadi itu sendiri. Bila mereka menilai pribadi berstatus rendah, pribadi tidak mendapatkan pelayanan istimewa. Bila pribadi dianggap bodoh, mereka akan mengatur pribadi. Untuk itu, pribadi secara sengaja menampilkan diri atau (self presentation) seperti apa yang ia kehendaki. Peralatan lengkap yang digunakan untuk menampilkan diri terdiri dari:

a. Panggung atau setting adalah rangkaian peralatan ruang dan benda yang digunakan.

b. Penampilan (appearance) berarti menggunakan petunjuk artifaktual.

c. Gaya bertingkah laku (manner), menunjukan cara bagaimana berjalan, duduk, berbicara, memandang, dan sebagainya. Presentasi diri merupakan upaya individu untuk menumbuhkan kesan 
tertentu di depan orang lain dengan cara menata perilaku agar orang lain memaknai identitas dirinya sesuai dengan apa yang ia inginkan. Dalam proses produksi identitas tersebut, ada suatu pertimbangan-pertimbangan yang dilakukan mengenai atribut simbol yang hendak digunakan sesuai dan mampu mendukung identitas yang ditampilkan secara menyeluruh.

Impression Management usaha seseorang untuk menampilkan kesan pertama yang disukai pada orang lain. Seperti halnya, seorang dokter menarik perhatian pasien dengan penampilan dan gayanya yang tampak profesional dan rapi. Begitu pula dengan hal nya dalam berbicara, seorang dokter akan banyak berbicara dengan penyusunan kalimat yang sopan, ditambah dengan beberapa istilah ilmiah kedokteran yang sering tidak dimengerti oleh orang awam.

Selain itu, pengelolaan kesan yang kuat juga dapat di dukung dari adanya setting panggung yang tepat, misalnya pada ruangan dokter yang tersedia berbagai alat medis, dan lengkap dengan tatanan pajangan hiasan yang menyangkut mengenai kesehatan. Ketika Impression Management telah berhasil dibangun oleh dokter pada pasiennya, pasien akan sepenuhnya mempercayai dokter. Kehidupan sosial manusia dalam berinteraksi dimana saja, kapan saja, selalu menampilkan dirinya sebagai pemain drama yang setiap saat dapat merubah penampilan tergantung pada konteksnya. Hal itu terjadi pada kehidupan kita, tanpa kita sadari kita selalu berinteraksi dalam "Adegan", pada setiap "Drama" kehidupan.

Hal tersebut dalam Teori Dramaturgi Erving Goffman bisa diasumsikan sebagai panggung depan seorang dokter. Namun, dibalik profesi sebagai seorang dokter, pasti juga memiliki berbagai peran dirumahny, seperti sebagai seorang istri, suami, ayah, ibu, anak atau bahkan menjadi seorang teman. Kehidupan menurut teori dramaturgi adalah ibarat teather, interaksi sosial yang mirip pertunjukan drama, yang menampilkan peran. Dalam memainkan peran menggunakan bahasa verbal dan perilaku non verbal dan mengenakan atribut tertentu. kehidupan sosial dibagi menjadi wilayah depan" (front region) yang merujuk peristiwa social bahwa individu bergaya menampilkan perannya dan wilayah belakang (back region) yang merujuk tempat dan peristiwa yang memungkinkan mempersiapkan perannya di wilayah depan. Panggung depan dibagi menjadi dua yaitu; front pribadi (personal front) dan setting atas alat perlengkapan. Dengan demikian menganalisis dramaturgi mengenai berhasil tidaknya seorang dokter memainkan perannya di hadapan pasien untuk melihat relasi dokter dan pasien di Rumah Sakit Umum dr. Zainoel Abidin Banda Aceh sangat penting.

Pendekatan Dramaturgi Erving Goffman pertama kali memperkenalkan pendekatan dramaturginya dalam buku The Presentation of Self In Everyday Life pada tahun 1959. Perpsektif dramaturgi melihat kehidupan ibarat teater, di mana manusia di manapun dan kapan pun selalu menampilkan dirinya seperti pemain drama yang setiap saat penampilannya dapat berubah-ubah bergantung pada konteksnya. Dramaturgi merupakan salah satu varian lain dari teori interaksionisme simbolik yang digagas oleh George Herbert Mead. Akar interaksi simbolik mengasumsikan realitas sosial sebagai proses dan bukan sebagai sesuatu yang dogmatis. Artinya, masyarakat dipandang sebagai sebuah interaksi simbolik bagi individu-individu yang ada di dalamnya. Ada tiga premis yang dibangun dalam interaksionisme simbolik, yaitu: pertama, manusia bertindak berdasarkan makna-makna; kedua, makna tersebut didapatkan dari interaksi dengan orang lain; dan ketiga, makna berkembang dan disempurnakan ketika interaksi berlangsung. Interaksi simbolik menganggap individu atau diri sebagai subjek dalam percaturan sosial, sebagai pelaku yang aktif dan proaktif.

Menurut Mead, sebelum seseorang bertindak, ia membayangkan dirinya dalam posisi orang lain dengan harapanharapan orang lain dan mencoba memahami apa yang diharapkan orang itu. Hanya dengan menyerasikan diri dengan harapan-harapan orang lain itulah interaksi menjadi mungkin. Berbeda dengan pendahulunya dalam melihat diri (self), Erving Goffman lebih memusatkan perhatiannya pada pelaksanaan audiensi sosial dengan diri sendiri yang disebut sebagai dramaturgi atau pandangan tentang kehidupan sosial sebagai serentetan pertunjukkan drama, seperti yang ditampilkan diatas pentas. Oleh karena itu, interaksi sosial yang mirip dengan pertunjukan di atas panggung, selalu menampilkan peran-peran yang dimainkan para aktor. Front pribadi terdiri dari alat-alat yang dapat dianggap khalayak sebagai perlengkapan yang dibawa aktor 
ke dalam setting, seperti dokter memaki jas putih, profesor diharapkan membawa buku teks berbahasa asing dan lain-lain. Front personal masih terbagi menjadi dua bagian, yaitu penampilan yang terdiri dari berbagai jenis barang yang mengenalkan status social actor dan gaya yang berarti mengenalkan peran macam apa yang dimainkan aktor dalam situasi tertentu. Panggung belakang yaitu ruang dimana disitulahberjalan skenario pertunjukan oleh "tim" (masyarakat rahasia yang mengatur pementasan masing-masing aktor). Back stage adalah keadaan di mana di belakang panggung dengan kondisi bahwa tidak ada penonton, sehingga setiap individu pemain dapat berperilaku bebas tanpa mempedulikan plot perilaku bagaimana yang harus kita bawakan.

Goffman mencontohkan bahwa seorang Dokter dapat sangat yakin (optimis) akan tindakan yang diperlihatkannya, atau sebaliknya (pesimis). Ketika sedang berinteraksi dengan pasien yang sedang sekarat dan gelisah karena penyakit parah yang dideritanya. Dokter menunjukkan suatu pertunjukkan, meyakinkan pasien bahwa "segalanya akan beres" dengan mendiagnosa dan memberikan resep obat tertentu, dan si dokter percaya (optimis) bahwa itu akan mengurangi penderitaan si pasien. Di sinilah pasien (penonton) bisa yakin dan menerima dari tindakan yang dilakukan atau ditunjukkan si Dokter tersebut. (Margaret M. Poloma, 2010 : 232).

Teori Dramaturgi membedakan penampilan (performance) dengan istilah panggung depan (frontstage) dan panggung belakang (backstage). Panggung depan adalah bagian penampilan individu yang secara teratur berfungsi di dalam mode yang umum. Didalamnya termasuk setting dan personal front. Dibagi menjadi penampilan (appearance) dan gaya (manner). Seorang dokter tindakan rutin sehari-harinya (fronstage) terjadi dalam suatu setting berupa kantor dengan perlengkapan yang sepatutnya. Penampilan (appearance) ditampakkan dengan jas putih dan steteskop yang tergantung dileher. Gaya (manner) ditunjukkan dengan sikap seorang dokter yang selalu percaya diri, tidak emosional dan tetap tenang ketika berinterkasi dengan pasien (Margaret M. Poloma, $2010: 233$ )

Teori Dramaturgi mengemukakan bahwa seseorang individu terkadang menyembunyikan atau mengesampingkan kegiatan, fakta dan motif yang tidak sesuai dengan citra dirinya, walaupun individu memiliki rutinitas, akan tetapi individu cenderung bertindak seolah-olah kegiatan rutin yang 'sekarang' itulah yang terpenting. Seorang dokter bisa jadi seorang petenis yang unggul atau seorang penyair amatir yang kreatif, akan tetapi ketika sedang tugas, kegiatan rutinnya sebagai dokter mengatasi semua peranan yang lain tersebut. Begitu juga halnya ketika dilapangan tenis, kegiatan rutinnya sebagai pemain tenis yang tangguh lebih tinggi ketimbang peranan sebagai dokter. (Margaret M. Poloma, 2010 : 233) Disamping panggung depan (fronstage), dalam teori Dramaturgi juga menyebutkan panggung belakang (backstage). Tindakan aktor/ individu ketika tidak berinteraksi tatap-muka dengan orang lain Pada saat jam istirahat, seorang dokter dalam ruang kantor pribadinya dan tidak berinteraksi dengan pasien (penonton) merupakan panggung belakang Sang dokter bisa melepaskan tindakan rutinnya sebagai dokter dengan melepas jasputihnya, duduk santai, dan bercanda dengan juru rawatnya. Sekalipun juru rawatnya menyaksikan dokter dalam keadaan demikian didalam panggung belakangnya, tidaklah demikian dengan para pasien. Beberapa saat, bila ada pasien yang menghadap dan menemui sang dokter untuk konsultasi, maka seketika menjadi panggung depan baginya. (Margaret M. Poloma, $2010: 234$ )

\section{Peran Penting Komunikasi Kesehatan}

Komunikasi kesehatan meningkatkan kesadaran individu tentang isu-isu kesehatan, masalah kesehatan, resiko kesehatan serta solusi kesehatan. Peningkatan kesadaran individu akan hal-hal tersebut ini berdampak pada keluarga serta lingkungan komunitas individu. Interaksi antara kesehatan dengan perilaku individu. Individu berada dalam situasi biologis, psikologis dan sosial kemasyarakatan. Ketiga faktor tersebut berpengaruh terhadap status kesehatan seorang individu. Melalui komunikasi kesehatan, kita mempelajari timbal balik antara ketiga faktor tersebut. Pemahaman ini penting agar kedepannya dapat dikembangkan intervensi program kesehatan yang bertujuan untuk mengubah perilaku individu menjadi lebih sehat. Kecenderungan yang terjadi belakangan ini, kebanyakan penyakit kronis justru disebabkan oleh faktor sosial dan pengaruh perilaku (behaviour). Banyak gangguan penyakit kronis yang disebabkan oleh ketidakmampuan 
individu untuk menjalani hidup sehat dan ketidakmampuan individu untuk bertanggungjawab atas status kesehatannya sendiri karena telah tenggelam dalam gaya hidup yang kurang sehat.

\section{Metode}

Penelitian ini merupakan penelitian kualitatif dengan pendekatan deskriptif yang bermaksud untuk memahami fenomena tentang apa yang dialami oleh subjek penelitian misalnya perilaku, persepsi, motivasi, tindakan dan lain-lain. Peneliti mengumpulkan data dengan teknik wawancara dan observasi. Informan atau narasumber dalam penelitian tiga orang dokter spesialis yang bekerja di Rumah Sakit Umum Daerah Zainoel Abidin Banda Aceh dan tiga orang pasien. Pemilihan informan berdasarkan banyaknya poliklinik yang dikunjungi dalam 3 bulan terakhir, yaitu Poliklinik Jantung, Poliklinik Saraf dan Poliklinik Penyakit Dalam. Penelitian ini memperoleh enam orang informan yakni Dr. Sarah Firdausa, Sp.PD Dokter Spesialis Penyakit Dalam 36 tahun, Dr. Nova Dian Lestari, Sp.S Dokter Spesialis Saraf 42 tahun, Dr. Sri Murdiati, Sp.JP Dokter Spesialis Jantung dan Pembuluh Darah 41 tahun, Nurhayati pasien di Poliklinik Penyakit Dalam 43 tahun, Safia pasien di Poliklinik Saraf 67 tahun, Malahayati pasien di Poliklinik Jantung 52 tahun.

\section{Hasil dan Pembahasan}

Berdasarkan hasil yang didapatkan peneliti melalui buku catatan sejarah Rumah Sakit Umum Daerah dr. Zainoel Abidin dan pengembangannya berlokasi di Jalan Tgk. Daud Beureueh No.108 Banda Aceh. Memiliki luas area $215.193 \mathrm{~m} 2$ dengan luas bangunan 54.785,13 m2. Rumah sakit ini berdiri pada tanggal 22 Februari 1979 yaitu atas dasar Keputusan Menteri Kesehatan No.551/Menkes/SK/2F/1979 Pada tahun 2011 menteri Kesehatan RI menerbitkan Surat Keputusan Nomor 1062/MENKES/SK/VI/2011 tentang peningkatan kelas RSUD dr. Zainoel Abidin Banda Aceh, sebagai Rumah Sakit Umum Daerah dengan klarifikasi Kelas A dan dilanjutkan dengan SK Menteri Kesehatan RI nomor HK.03.05/III/327/2011 tentang penetapan RSUD dr. Zainoel Abidin Banda Aceh sebagai Rumah Sakit Pendidikan Utama Fakultas Kedokteran Universitas Syiah Kuala Banda Aceh. Goffman mengatakan bahwa kehidupan social itu dibagi menjadi "wilayah depan" (front region) dan "wilayah belakang" (back region), wilayah depan merujuk kepada peristiwa sosial yang menunjukkan bahwa individu bergaya atau menampilkan peras formalnya. Mereka sedang memainkan perannya diatas panggung sandiwara dihadapan khalayak penonton. (Widodo, 2010:167)

Informan pertama, Seorang Dokter Spesialis Penyakit Dalam. dr. Sarah Firdausa, Sp.PD. Peneliti menemui informan tersebut pada pagi Jum'at/ 16 November 2018. Saat itu dr. Sarah, Sp.PD sedang melaksanakan tugasnya di Poliklinik Penyakit Dalam RSUDZA. Hal pertama yang peneliti lakukan adalah wawancara mendasar sekaligus perkenalan terlebih dahulu. Informan pertama ini, sangat welcome dan ramah, namun disela-sela ada pasien yang datang menemuinya, ia seperti terburu-buru ingin mengakhiri wawancara.

Peneliti merasa, kalau informan tidak suka di ganggu waktu kerjanya, peneliti meminta izin untuk tunggu diluar, hingga waktu jam kerja selesai. Informan ini bersikap ramah dengan pasien yang ia temui, ia bahkan sesekali tersenyum dan membuat lelucon kecil agar pasien dapat tertawa. Penampilan informan sebagai seorang dokter tampak sangat sederhana, ia juga tidak menggunakan jas putih khas dokternya pada saat melayani pasien. Hanya saja, ia sering menggunakan bahasa dengan istilah kedokteran dalam menjelaskan sesuatu kondisi yang dialami oleh pasiennya. Sampai terkadang, seorang pasien menanyakan kembali mengenai apa yang dimaksud dengan penjelasanya. Pada Sabtu, 17 November 2018 peneliti menjumpai kembali informan di luar jam kerjanya sebagai seorang dokter di RSUD dr. Zainoel Abidin, ia terlihat duduk menyendiri disudut kantin Rumah Sakit, sambil sesekali memperhatikan labtopnya, ia juga masih mau menjawab semua pertanyaan-pertanyaan peneliti. Namun, jawaban yang ia berikan terbilang sangat singkat, dan cuek. Ia sering menyebutkan kata, " ya, seperti itulah" atau "kadang gak juga ya". Keseharian informan ini hanya antara Rumah, RSUD dr. Zainoel Abidin dan Kampus 
tempat ia mengajar. Terkadang pada sore hari, ia baru pulang untuk beristirahat di rumah. Informan memiliki hobi travelling, ia sering melakukan travelling bersama teman-teman se-profesinya, kadang juga bersama keluarganya, Informan sudah menikah 13 tahun dan belum memiliki anak.

Informan ini, masih sangat dini dalam profesi yang ia tekuni saat ini. Ia baru setahun menjadi dokter spesialis penyakit dalam. Namun, setelah ia tekuni untuk ke depannya ia masih ingin memperdalam kembali ilmu kedokteran yang saat ini ia tekuni sebagai sebuah profesi.

"Selain antara rumah, rumah sakit dan kampus saya juga sering ke warung kopi untuk mengerjakan tugas mengajar," tutur informan pertama, dr. Sarah Firdausa, Sp.PD saat ditanyai peneliti pada wawancara penelitian, Jum'at, 16 November 2018.

Pada panggung depan, informan ini sangat pandaimemunculkan impression management atau pengelolaan kesan yang ada. Ia membuat pasien yang ia tangani selalu berpikir positif mengenaidirinya. Ia juga kerap sekali menampilkan penampilan yang sederhana dan menolak pujian yang diberikan pasien kepadanya.

Ia sering mengatakan "gak ah, berlebihan si ibuk" ketika ada satu orang pasienyang kebetulan ada diruangannya bersama peneliti yang saat itu sedang mewawancarai informan.Ia berhasil membungkus kesan yang baik pada pasiennya, sehingga pasien yang ia tangani selalu memberikan nilai-nilai positif terhadap informan. Peneliti, merasa bahwa informan ini terbilang sangat tertutup, ia hanya menjawab pertanyaan yang diajukan dengan sekedarnya saja, dan ia sering mempertegas jawaban agar pertanyaannya yang telah ditanyakan tidak untuk ditanyakan kembali.

Hal ini, sedikit membuat penelitian kesusahan dalam mendapatkan informasi dan melihat panggung belakang seorang dokter. Namun melalui pasiennya peneliti mendapat fakta bahwa, pasien tersebut sering terlihat berdiam diri dan beristirahat di masjid. Hal ini merupakan sebuah panggung belakang yang luar biasa, dibalik sifat cueknya yang terlihat di panggung belakang lainnya selain dihadapan peneliti. Kesimpulan dari peneliti yang melakukan observasi dan hasil wawancara bersama informan pertama, informan pertama bersifat sederhana, cuek dan tertutup. Namun, informan begitu ramah ketika berhadapan dengan pasien dan suka bercanda. Goffman mengakui bahwa orang tidak selamanya ingin menunjukkan peran formalnya dalam panggung depannya, orang mungkin memainkan suatu perasaan, meskipun ia menunjukkan keengganannya untuk memainkannya padahal ia senang akan peran tersebut. Akan tetapi menurut Goffman, ketika orang melakukan hal semacam itu, mereka tidak bermaksud membebaskan diri sama sekali dari peran social atau identitas mereka yang formal itu, namun karen ada perasaan social dan identitas lain yang menguntungkan mereka. (Widodo, 2010:112)

Informan kedua adalah Seorang Dokter Spesialis Saraf, dr. Nova Dian Lestari, Sp.S, peneliti menemui informan tersebut pada Rabu, 28 November 2018, Informan begitu ramah dan lebih terbuka dibandingkan dengan informan pertama, beliau senang bercerita.Terkadang informan akan bercerita jauh lebih banyak dan lebih rinci dari pertanyaan yang peneliti ajukan kepadanya. dr. Nova, Sp.S sudah sejak tahun 2010 menjadi dokter spesialis Saraf di RSUD dr. Zainoel Abidin, selain di RSUD dr. Zainoel Abidin beliau juga berpraktik di RS Harapan Bunda Banda Aceh, dan di Apotek Laris pada malam harinya. Beliau juga sebagai staf pengajar di Fakultas Kedokteran Universitas Syiah Kuala. Selebihnya ia sering menghabiskan waktu bersama ketiga putra-putrinya. Dr.Nova, Sp.S juga termasuk orang yang Fasionable dalam berpenampilan, namun juga tak lupa dengan keharusannya dalam menutup aurat, ia sering menggunakan jilbab yang simple dan lebar, beberapa kali peneliti menemui nya ia sering menggunakan kerudung yang praktis tapi tetap modis dan pandai memadukan warna pakaiannya. Dr.Nova, Sp.S merupakan informan yang sulit ditebak panggung depan dan panggung belakangnya, dikarenakan saat ia melakoni dirinya sebagai seorang dokter dihadapan pasiennya juga sama dengan ia melakoni dirinya sebagai seorang ibu terhadap anak-anaknya. Kerap sekali ia sangat bersabar ketika, putranya yang masih berusia 7 tahun sering menganggunya dalam bekerja. Ia tetap menggunakan bahasa yang santun dan lembut dalam menegur sang putra. Begitu pula, ketika peneliti menjumpainya diluar jam kerja di RSUD dr.Zainoel Abidin Banda Aceh, ia sering membawa serta anaknya yang paling kecil kemanapun ia pergi. " Hafiz selalu ikut saya kemana saya pergi, hampir setiap waktu saya bawa dia, dan hampir 
setiap hari memang saya abiskan waktu saya dengan dia, antar jemput dia sekolah, mengaji dan bimbingan belajar," ujar dr. Nova, Sp.S saat peneliti bertanya mengenai keberadaan putranya di praktik pribadinya.

Informan memiliki kesenangan menanam bunga dan berkebun, informan juga lebih mendalami sifat dan karakter pasien yang ia jumpai, dan lebih baik dalam bersikap. Impression Management yang informan tunjukkan kepada pasien juga hampir sama dengan kehidupan kesehariaanya. Sehingga untuk menumbuhkan kesan yang baik dihadapan pasien bukan suatu hal yang sulit baginya. "bagi saya komunikasi yang baik kepada pasien sangat perlu ya, nasehat dan semangatlah lebih tepatnya," Ia juga bercerita, terkadang karena kita bisa membuat pasien nyaman, ia juga akan tenang dan senang untuk berobat, padahal terkadang ia hanya memberikan obat yang sama dengan sebelumnya, tetapi pasien merasa lebih tenang, dan tidur juga lebih pulas, "sugesti ada, tapi pasien sendiri yang menciptakannya tanpa ia sadari," Ketika peneliti menjumpai informan di luar jam kerjanya di RSUD dr. Zainoel Abidin, informan juga bersikap biasa saja, seperti adanya. Yang dapat diambil ketika peneliti mendapatkan ia bekerja pakai mobil, memakai tas branded, baju yang fasionable, namun ketika dirumah ia senang menanam bunga dan berkebun dengan menggunakan baju daster yang santai dengan kerudung seadanya dan warna pun tidak sepandan. Ia juga memakai sendal jepit ketika ia berkebun. Ia juga sering menyulang nasi anaknya yang kecil ketika sedang makan. Kesimpulan yang dapat diambil dari informan Kedua ini adalah panggung depan dan panggung belakangnya susah ditebak, karena cara ia berkomunikasi maupun bersikap sama saja, namun dapat dilihat dari cara ia berpakaian dan bersikap berbeda dari seorang yang memiliki profesi sebagai dokter spesialis dan sebagai seorang ibu bagi anak anaknya, dan sebagai seorang perempuan yang memiliki hobi menanam bunga.

Informan ketiga Dr. Sri Murdiati, Sp,JP, adalah informan ketiga yang ditemui peneliti, informan ini merupakan 1 dari 2 dokter spesialis jantung perempuan yang ada di RSUD dr. Zainoel Abidin Banda Aceh. Dr. Sri, Sp.JP juga memiliki hobi yang sama dengan informan pertama yaitu senang travelling bersama teman dan sanak saudaranya untuk melepaskan penat dari profesinya sebagai dokter spesialis jantung. Tak heran, karena ia selalu memeriksa pasien jantung setiap jadwal polinya berkisar 100 sampai 300 pasien seorang diri. Poliklinik Jantung dan Pembuluh darah merupakan, Poliklinik yang memiliki pasien terbanyak pada RSUD dr. Zainoel Abidin Banda Aceh. Tidak heran juga penyakit Jantung adalah penyakit yang mengharuskan penderitanya untuk berobat dan mengontrol secara rutin setiap bulannya, dan tidak boleh putus obat. Hal itu untuk dapat mengurangi gejala jantung koroner dan serangan jantung yang bisa terjadi kapan saja pada penderita penyakit jantung dr .Sri, Sp.JP juga merupakan dokter yang bersedia dan bahkan menyarankan pasiennya untuk menghubunginya ketika ada sesuatu hal yang ingin ditanyakan langsung kepadanya.

Informan ini juga berpenampilan sangat sederhana bahkan sering pergi ke Rumah Sakit atau kemana pun memakai jasa gojek online, dikarenakan ia yang tidak bisa mengemudi kendaraan sepeda motor atau mobil. Bahkan ia tak segan-segan menawarkan diri untuk diantar kepada mahasiswa atau perawat di Rumah Sakit. Impression Management yang ia tunjukkan kepada pasiennya sama seperti informan dokter yang lainnya. Ia tersenyum ramah dan tidak pernah menyepelekan penyakit yang di derita pasien. Dan ia selalu memberikan nasehat kepada pasien yang berterima kasih kepadanya, "Saya selalu bilang, Allah yang menyembuhkan bukan saya. Berterima kasihlah kepada Allah," tutur dr. Sri, Sp.JP. Kesimpulannya, Informan ketiga ini ia mampu membangun sebuah Impression management kepada pasien yang ia tangani, bahkan ia sangat sering mendapatkan buah tangan atau oleh-oleh dari pasiennya, karena bentuk perhatian yang ia berikan terkadang membuat pasien merasa sangat nyaman dan lebih baik dari sebelumnya. Namun, panggung belakang yang tampak pada pasien adalah dokter sering datang terlambat, dan sangat sering tidak ada dipraktik karena beliau sedang mengikuti pendidikan sub spesialis di Jakarta. Goffman juga menjelaskan mengenai personal front dan setting front pribadi terdiri dari alat-alat yang dianggap khlayak sebagai perlengkapan yang dibawa aktor ke dalam setting, misalnya dokter diharapkan mengenakan jas dokter dengan stetoskop menggantung dilehernya. Personal front mencakup bahasa verbal dan bahasa tubuh sang aktor. Misalnya, berbicara sopan, 
pengucapan istilah-istilah asing, intonasi, postur tubuh, ekspresi wajah, pakaian, penampakan usia dan sebagainya.

Panggung Belakang (Back Stage). Goffman juga menjelaskan mengenai panggung belakang, yang merujuk kepada tempat dan peristiwa yang memungkinkan mempersiapkan perannya di wilayah depan. Wilayah depan ibarat panggung sandiwara bagian depan (front stage) yang ditonton khalayak penonton, sedang wilayah belakang ibarat panggung sandiwara bagian belakang (back stage) atau kamar rias tempat pemain sandiwara bersantai, mempersiapkan diri, atau berlatih untuk memainkan perannya di panggung depan. (Widodo, 2010:167)

Informan keempat, adalah seorang ibu rumah tangga yang menderita sakit pada lehernya. Dan kemudian berobat pada poliklinik penyakit dalam, dan ditangani awal oleh dr. Sarah Firdausa, Sp.PD. Nurhayati, mengaku sudah kali ke 3 berobat disini dan ditangani oleh dokter yang sama, "Saya berobat setiap hari Jum'at dan kebetulan dr. Sarah jaga polinya hari Jum'at juga", jawab Nurhayati ketika diwawancarai oleh peneliti setelah ia keluar dari ruangan dokter pada Jum'at, 16 November 2018 lalu. Nurhayati tampak biasa saja ketika, peneliti bertanya-tanya mengenai dr. Sarah, Sp.PD. Bagi ia dr. Sarah, Sp.PD sama saja dengan dokter lainnya, ramah dan bagi ia dr.Sarah, Sp.PD hanya bersifat biasa saja, tanpa ada yang dilebih-lebihkan. "Ketika saya masuk setiap hari saat berobat, beliau hanya menanyakan kabar, dan apa yang sakit saja," ujar Nurhayati saat diwawancarai oleh peneliti. Nurhayati juga mengatakan bahwa pecan selanjutnya ia akan dirujuk pada dokter spesialis penyakit dalam yang lebih spesifik melayani bagian kelenjer pada lehernya. Dikarenakan dr. Sarah, Sp.PD hanya melayani bagian penyakit dalam secara umum saja. "Kemaren ke poli ini dulu, karna belum diidentifikasi sakit saya apa, dan belum tau ciricirinya,"tutur Nurhayati. Panggung belakang yang peneliti liat dari seorang dokter yang menangani pasien ini adalah dr. Sarah Firdausa, Sp.PD, dokter tersebut memiliki impression management seadanya ketika di hadapan pasien, bahkan ia memilih bersikap cuek dan tidak suka dengan pujian pasiennya, namuan dibalik sifat itu, pasiennya tanpa sengaja sering bertemu dengan dokter di masjid, sedang melakukan ibadah atau hanya sekadar beristirahat sebentar saja, hal ini secara tidak langsung sudah membuat panggung belakang seorang dokter ini sangat tampak.

Informan kelima Safia, adalah seorang pensiunan yang menjadi salah satu pasien Saraf yang hampir setiap kali berobat datang kepada dr.Nova, Sp.S. Safia, yang berusia 67 tahun, memiliki penyakit nyeri pada sendinya. Informan ini dijumpai peneliti pada Rabu, 28 November 2018. Ia bercerita bahwa, dr.Nova, Sp.S merupakan dokter yang selama ini menangani penyakitnya, bahkan ia juga mengakui bahwa tidak berobat ke dokter spesialis saraf lainnya, hanya pada dr.Nova, Sp.S saja. "Dokter ini, baik ya. Ramah juga saya sering diberikan obat yang itu-itu saja, tapi Alhamdulillah cocok-cok saja ya," ujar Safia. Namun, Safia juga bercerita terkadang dr.Nova, Sp.S sering datang terlambat ketika ia berobat. Ia memakluminya karena juga dr.Nova, Sp.S pasiennya terbilang ramai dan ada di dua rumah sakit berbeda Safia yang merupakan pasien rutin dari dr.Nova Dian Lestari, Sp.S, merupakan cerminan panggung belakang seorang informan, ia mengakui bahwa ia sendiri sangat nyaman berobat dan mengontrol atau berkonsultasi mengenai kesehatannya kepada dokter tersebut. Hanya saja yang bersangkutan sering datang terlambat atau tidak sesuai pada waktu yang telah dijanjikan. Hal demikian, terkadang juga membuat Safia merasa kecewa, karena ia harus menunggu begitu lama hanya untuk berobat saja.

Panggung belakang dari dokter dengan pasien ini adalah dr. Nova Dian Lestari, Sp.S, dokter ini yang memiliki impression management yang sangat bagus dan kuat didepan pasien maupun pada kegiatan sehari-harinya. Namun, panggung belakang seorang dokter ini bisa dilihat dari penampilan dan cara berpakaiannya.

Informan keenam Ny. Malahayati, Informan terakhir yang dijumpai oleh peneliti adalah seorang guru Sekolah Dasar. Penderita penyakit Jantung yang sudah sering berobat dengan dr.Sri, Sp.JP, ia bercerita mengenai kerendahan hati dokter ini, yang sering menerima dengan lapang dada ketika ia menghubungi beliau diluar jam kerja, "Terkadang saya sering sekali menghubungi nya malam-malam", tutur Malahayati. Ia juga mengatakan kalau dokternya sering sulit dijumpai, karena sedang melanjutkan sekolah diluar kota. Hal itu sangat disayangkannya. Pasien terakhir 
yang peneliti jumpai adalah pasien yang ditangani langsung oleh dr. Sri Murdiati, Sp.JP, panggung belakang sosok dokter ini di dapati dari pasiennya, dokter ini juga memakai impression management yang baik, sehingga pasiennya sangat menyukai dan terpikat dengan perlakuan yang dokternya tunjukkan.

Panggung depan (front stage) Rumah Sakit Umum Daerah (RSUD) dr. Zainoel Abidin Banda Aceh, merupakan satu satunya Rumah Sakit Terbesar di Aceh dan menjadi rujukan akhir dari fasilitas kesehatan (Faskes), hanya pasien yang dirasa betul-betul mengalami tingkat tertinggi masalah penyakitnya yang akan dirujuk ke RSUD dr. Zainal Abidin. Sejak pukul 06.30 wib pagi hari telah ramai pasien berantrian memadati jalur pendaftaran untuk berobat, jalur terbagi dua yaitu, melalui Unit Gawat Darurat (UGD) dan melalui Poliklinik Spesialis. Melalui UGD adalah untuk pasien yang sudah dalam keadaan darurat, yang harus diutamakan pelayanannya oleh dokter spesialis. Poliklinik Spesialis adalah untuk pasien yang masih bisa terbilang sehat dan masih dapat berobat jalan. Kedua jalur ini sama-sama bertitik temu di Dokter Spesialis. Perbedaannya, jika melalui jalur UGD langsung Dokter Spesialisnya yang mendatangi pasien untuk memeriksa dan memberi tindakan sesuai dengan penyakitnya. Bahkan ada beberapa dokter spesialis yang berjaga untuk stand by di UGD setiap waktu.

Begitu pula dengan pasien yang mengikuti jalur rawat jalan, setelah proses pendaftaran pasien akan menuju pada poliklinik spesialis yang sesuai dengan rujukan penyakit pasien. Setelah mengikuti prosedur pendaftran di area poli, menyerahkan berkas dan mengambil nomer antrian pasien di persilahkan duduk pada bangku poliklinik yang telah disediakan oleh masing-masing poliklinik. Pasien akan masuk ke ruangan pemeriksaan dokter spesialis sesuai dengan nomer antrian yang telah ada. Setiap sisi ruangan poliklinik sudah di desain sama semuanya sesuai dengan ketentuan rumah sakit, meja pendaftaran Ruang periksa dokter spesialis, ruang untuk dokter PPDS dan dokter Coas, ruang tindakan, serta sebuah toilet. Pasien terlebih dahulu akan diperiksa secara mendasar oleh dokter PPDS atau dokter Coas. Dokter PPDS adalah Dokter umum yang sedang mengambil pendidikan untuk menjadi dokter spesialis, sedangkan dokter coas adalah mahasiswa Ilmu Kedokteran yang sedang mengambil mata kuliah akhir praktik langsung ke Rumah Sakit. Hal ini karena RSUD dr. Zainoel Abidin adalah Rumah Sakit Pendidikan di Provinsi Aceh.

Pemeriksaan mendasar yang dilakukan oleh dokter PPDS, adalah pemeriksaan tekanan darah, pemeriksaan tekanan jantung, pemeriksaan denyut nadi dan beberapa pemeriksaan lainnya. Setelah itu pasien akan masuk ke ruang dokter spesialis bersama dengan dokter PPDS yang menjadi dampingannya, ia akan menjelaskan penyakit dan gejala apa saja yang didapat dari keterangan yang pasien berikan. Ruangan pemeriksaan dokter spesialis di desain dengan warna serba putih, ada tiga kursi, satu komputer dan beberapa bangku dibelakang bangku pasien utama, bangku tersebut biasanya diisi oleh pasien selanjutnya yang akan diperiksa setelah pasien yang sedang diperiksa.

Dokter akan menanyakan kabar terlebih dahulu setelah membaca hasil mendasar dari rekam medis pasien, setelah itu pasien akan diperiksa ulang kembali, pemeriksaan mendasarnya. Dokter akan mendengarkan keluhan pasien untuk setiap sakit yang dirasa. Setelah itu dokter akan menuliskan daftar obat yang harus dikonsumsi pasien pada lembar resep obat. Seorang Dokter, selalu berhasil menampilkan pengelolaan kesan atau impression management yang baik pada pasiennya, seperti dari segi penampilan dan gaya. Dokter berpenampilan seperti, memakai jas putih berlengan panjang, memakai bed nama dari Rumah Sakit dan memakai staterskop yang digantungkan di lehernya. Dokter juga lebih sering memakai kata baku dalam berbicara, dan terkadang sering sekali memakai kata ilmiah bahasa kedokteran, untuk lebih menonjolkan khasnya seorang dokter. Dan dokter sangat sering menyebutkan dirinya sebagai "Dokter" bukan sebagai "Saya" dalam berbicara kepada perawat, tim administrasi lainnya.

Settingan atau tempat pertunjukkan seorang dokter adalah sebuah ruangan poliklinik, yang di desain serba putih, dengan disetiap sisi dinding berhias gambar-gambar struktur organ manusia menurut spesialisasi nya, dilengkapi dengan sebuah tempat tidur pasien, meja dengan tiga kursi. Di atas meja di penuhi dengan tumpukan berkas status pasien, sebuah komputer, beberapa buku resep, 
dan sebuah sterteskop atau lebih dikenal dengan alat pendengar detak jantung. Dan ada salah seorang perawat yang bolak-balik memanggil pasien yang akan berobat.

Dokter yang menjaga poliklinik, akan tersenyum ramah dan memulai percakapan dengan sangat santun, menanyai kabar, bagian yang sakit dan apa keluhan pasien lainnya. Demikianlah yang disebut dengan Impression management. Goffman dalam Ritzer george (2010) juga mengasumsikan bahwa ketika orang-orang berinteraksi, mereka ingin menyajikan suatu gambaran diri yang akan diterima oleh orang lain. Goffman menyebut upaya itu sebagai "pengelolaan kesan" (impression management), yakni teknik teknik yang digunakan oleh aktor untuk memupuk kesankesan tertentu, dalam situasi tertentu untuk mencapai tujuan tertentu. Panggung depan atau Front Stage pada masing-masing dokter dengan poliklinik yang berbeda juga dapat dilihat dari salah satu pertanyaan yang peneliti ajukan kepada ketiga dokter tersebut yaitu, mengenai kendala apa saja yang dialami dokter dalam menghadapi pasien.

“...terkadang hanya timbul rasa malas saja ketika hendak pergi ke Rumah Sakit...” ( dr. Sarah Firdausa, Sp.PD) “...Kendala dalam melayani, kadang ada juga beberapa pasien dengan sistem pembayaran mandiri yang suka komplain, tapi sangat jarang sekali. Kalau pasien BPJS biasanya tidak banyak tingkah, terima-terima saja...” (dr. Nova Dian Lestari, Sp.S) “...Kalau dari diri sendiri, zaman yang semakin berkembang, makin canggih, yaa solusinya belajar lagi yaa, kadang terkendala juga di rumah sakit yang banyak sekali mewajibkan dokter mengisi status pasien..." (dr. Sri Murdiati, Sp.JP).

Masing-masing dokter juga memiliki penjelasan yang berbeda tehadap pasiennya dalam hal pemberian sugesti untuk kesembuhan pasiennya. Hal ersebut dapat dilihat dari hasil wawancara peneliti dengan ketiga dokter dengan jenis spesialis yang berbeda.

"...Saya rasa bukan sugesti ya, lebih tepatnya edukasi seperti tentang penyakitnya, mengenai obat yang harus diminum, dan resikonya kalau tidak minum obat..." (dr.Sarah Firdausa, Sp.PD) “...Bukan sugesti, tapi lebih ke nasehat aja sih, semangat. Biasanya kan pasien bukan hanya obat saja yang diperlukan, tetapi juga lebih ke bagaimana kita berkomunikasi dengan pasiennya. Memberikan rasa nyaman...” (dr. Nova Dian Lestari, Sp.S). “...Saya selalu menyampaikan ke pasien, banyak berdoa, insyaallah yang menyembuhkannya Allah bukan saya..."(dr. Sri Murdiati, Sp.JP).

Panggung Depan atau Front Stage seorang dokter juga dapat kita lihat, melalui pertanyaan yang diajukan peneliti terhadap ketiga dokter dengan spesialis berbeda, pertanyaannya terkait bagaimana tanggapan mereka jika ada pasien yang menghubungi mereka diluar jam kerja.

“...Banyak pasien yang menghubungi saya diluar jam kerja, kalau saya bisa jawab saya jawab, terkadang memang menyebalkan sih, menggangu tidur kita tapi itu sudah menjadi konsekuensi saya sebagai dokter...” (dr. Sarah Firdausa, Sp.PD) "...Ada, saya menyarankan via whattshap saja, kalau tidak begitu genting...” (dr. Nova Dian Lestari, Sp.S)

\section{Panggung Belakang (Back Stage)}

Dalam penelitian ini Panggung belakang atau back stage seorang dokter, dilihat dari pasien yang telah tiga kali berkunjung ke RSUDZA dan mendapatkan pelayanan dari tiga orang dokter yang menjadi responden dalam penelitian ini. Pada panggung belakang sangat tampak keberhasilan impression management yang telah dibangun dokter terhadap pasiennya, sehingga juga sangat sulit untuk membedakan panggung belakang atau sikap yang ditampilkan dokter kepada pasiennya.

Dalam hasil wawancara peneliti, dengan tiga responden dari pasien dengan kategori dan penyakit yang berbeda :

“...Saya sering jumpa dokter itu di Mesjid oman, dia ramah. Dia selalu mengingatkan makanan yang harus saya pantang, ada juga ketika selesai berobat dia ucapkan cepat sembuh ya buk...” (Ny.Nurhayati, 43 tahun Pasien Penyakit Dalam ).

“...Dokternya ramah dan lembut sekali, alhamdulillah pelahan-lahan hilang nyeri di lutut saya, hanya saja kata dokternya ini sudah terjadi pengikisan secara perlahan, mungkin juga karna faktor usia..." (Ny. Safia, 70 tahun, Pasien Saraf) “...Sering sekali dokternya mengingatkan kalau ada sesuatu langsung hubungi dia, tapi kadang saya sungkan...” (Ny. Malahayati, 52 tahun, Pasien Jantung). 
Tindakan aktor atau individu ketika tidak berinteraksi tatap-muka dengan orang lain pada saat jam istirahat, seorang dokter dalam ruang kantor pribadinya dan tidak berinteraksi dengan pasiennya (penonton) merupakan panggung belakang sang dokter bisa melepaskan tindakan rutinnya sebagai dokter dengan melepas jas putihnya, duduk santai, dan bercanda dengan juru rawatnya. Sekalipun juru rawatnya menyaksikan dokter dalam keadaan demikian didalam panggung belakangnya, tidaklah demikian dengan para pasien. Beberapa saat, bila ada pasien yang menghadap dan menemui sang dokter untuk konsultasi, maka seketika menjadi panggung depan baginya (Margaret M. Poloma, 2010:234) Panggung belakang seorang dokter, juga dapat dilihat dari kepribadiaannya dan latar belakang kehidupannya. Dokter yang telah lama menjadi seorang dokter di Rumah Sakit Daerah akan lebih mudah mengenali karakteristik seorang pasien, dan lebih tampak impression management dan penuturan komunikasinya ketimbang dokter yang baru menjadi dokter spesialis di Rumah Sakit Daerah.

\section{Relasi Dokter dan Pasien}

Hubungan yang dibangun oleh dokter dan pasien sejauh penelitian ini berlangsung sangat baik, seorang dokter mampu menghidupkan impression management kepada setiap pasien yang datang berobat. Dalam penelitian ini, peneliti hanya mengambil tiga spesialis saja untuk menjadi objek pada penelitian. Hal ini dibatasi, agar peneliti dapat melihat lebih dalam dan akurat mengenai relasi dokter dan pasiennya. Peneliti memilih, spesialis yang jumlah pasien polikliniknya terbanyak dalam tiga bulan terakhir, yaitu bulan Agustus, September dan Oktober 2018. Dari 12 Poliklinik di RSUDZA dalam penelitian ini, ada tiga poliklinik dengan jumlah pasien terbanyak dalam tiga bulan terakhir. Dalam data yang didapatkan peneliti dari bagian Rekam Medik RSUDZA bahwa poliklinik terbanyak adalah Poliklinik Penyakit Dalam, disusul dengan poliklinik saraf, dan terakhir poliklinik Jantung dengan jumlah pasien terbanyak diantara dua lainnya. Melalui pengamatan, observasi dan studi lapangan yang dilakukan oleh peneliti ketiga poliklinik tersebut memiliki rata-rata melayani pasien lebih dari 100 hingga 200 orang setiap harinya.

Satu pasien hanya diperiksa \pm 8 sampai 15 menit per pasiennya. Dengan penanganan dua orang dokter per poliklinik setiap harinya. Relasi dokter dan pasien dalam setiap pertemuan tatap muka, sangatlah baik. Dokter memiliki impression management yang sangat baik kepada setiap pasiennya, terkadang mengeluarkan kesan dingin pada wajahnya, namun tetap tampak ramah dan tersenyum. Menanyakan kabar dan kemudian menanyakan perkembangan kesembuhan atau menanyai mengenai keluhan apa saja yang dirasakan pasien. Setelah itu, dokter hanya menuliskan resep dan terkadang memberitahu apa yang menjadi pantangan dan larangan untuk pasien dengan jenis penyakitnya. Dramaturgi merupakan teori yang dicetus oleh Erving Goffman.

Menurut Goffman, diri bukan milik aktor tetapi lebih sebagai hasil interaksi dramatis antara aktor dan audiens. Diri adalah "pengaruh dramatis yang muncul dari suasana yang ditampilkan". Karena diri adalah hasil interaksi dramatis, maka mudah terganggu selama penampilannya. Dramaturgi Goffman memperhatikan proses yang dapat mencegah gangguan atas penampilan diri. (George Ritzer:2003) Goffman berasumsi bahwa saat berinteraksi, aktor ingin menampilkan perasaan diri yang dapat diterima oleh orang lain. Tetapi, ketika menampilkan diri, aktor menyadari bahwa anggota audien dapat menganggu penampilannya. Teori dasar Dramaturgi yang mendasari penelitian ini, Yang menjadi aktor pada penelitian ini adalah Tiga orang dokter dengan spesialis yang berbeda, dan pasien mereka adalah audien, yang menjadi panggungnya adalah rumah sakit.

Dalam proses panggung depan atau front stage dokter menumbuhkan berbagai impression management kepada pasiennya. Dapat dilihat, dari segi penampilan, sikap dan cara berkomunikasi yang membuat interaksi antara dokter dan pasien menjadi sebuah komunikasi yang baik. Teori dramaturgi adalah teori yang menjelaskan bahwa interaksi sosial dimaknai sama dengan pertunjukkan teater atau drama diatas panggung, manusia adalah aktor yang berusaha untuk menggabungkan karakterstik personal dan tujuan kepada orang lain, melalui pertunjukkan dramanya sendiri (Widodo, 2010:167). 


\section{Kesimpulan}

Berdasarkan hasil penelitian dan pembahasan dapat ditarik kesimpulan sebagai berikut: Informan yang sudah sekian lama berprofesi sebagai dokter mengatakan pengeloloaan kesan (impression management) yang ia kelola sudah sangat baik di hadapan pasien selaku audiensnya. Semakin lama ia bergelut pada profesinya akan semakin sulit peneliti membedakan panggung depan dan panggung belakangnya. Pengelolaan kesan sangat berpengaruh pada panggung depan (front stage), dalam teori dramaturgi. Secara keseluruhan, pemetaan panggung depan para informan hampir sama semuanya, di panggung depan para informan menunjukkan bahwa komponen komponen panggung depan merupakan pengelolaan kesan dalam usaha menampilkan citra diri dengan komponen busana, sikap, dan latar panggung depan. Penampilan (appearance) dan sikap (manner) yang ditampilkan oleh seorang dokter di panggung depan, dibentuk sesuai citra yang ingin mereka tampilkan. Panggung belakang (back stage) yang didapatkan oleh peneliti melalui informan yang telah ditentukan adalah yang menjadi panggung belakang, atau saat seorang dokter tidak sedang memerankan dirinya sesuai dengan profesinya mereka akan menjadi apa adanya sesuai dengan pola kehidupan masing-masing. Ada yang senang menggunakan hobinya untuk menghabiskan waktu luangnya dengan menggunakan baju daster seadanya, ada pula yang menghabiskan waktu luangnya di warung kopi dan ada pula yang mengikuti kegiatan bermasyarakat. Bahkan tanpa informan sadari kegiatan yang selama ini lebih lama ia lakoni adalah merupakan panggung belakang dari profesinya sebagai seorang dokter. Dokter dengan spesialis jenis penyakit yang lebih serius dan memerlukan waktu seumur hidup dalam proses penyembuhan, memiliki rasa lebih terbuka kepada pasien saat di panggung depan ketika ia juga berada di panggung belakang. Ia lebih terbuka dalam berkomunikasi dan menunjukkan keseimbangan front stage dan back stage dalam teori dramaturgi.

\section{Daftar Pustaka}

Ardianto, Elvinaro dan Bambang Q-Anees, (2007), Filsafat Ilmu Komunikasi, Bandung: Simbiosa Rekatama Media

Dayakisni, Tri \& Hudaniah. 2009. Psikologi Sosial. Malang: UMM Press

Dianne Berry (2007). Health Communication: Theory and Practice, New York: McGrawHill Education

Deddy Mulyana, (2004). Ilmu Komunikasi: Suatu Pengantar. Bandung : Rosdakarya 2004

Edelmann, R.J. (2000). Psychosocial Aspects of the Health Care Process. London: Prentice Hall.

Effendy, Onong Uchjana. (2005). Ilmu Komunikasi Teori dan Praktik, Bandung: Remaja Rosdakarya

Elbadiansah, Umarso. (2014). Interaksionisme Simbolik dari Era klasik hingga Modern. Jakarta: Raja Grafinddo Persada.

Goffman, Erving. (1959). The Presentation of Self in Everyday Life. Jakarta: Erlangga.

Liliweri, Alo. (2011). Komunikasi Serba Ada Serba Makna. Jakarta : Kencana (2008). Dasar-dasar Komunikasi Kesehatan. Jakarta : Pustaka Pelajar.

Miles, M.B \& Huberman A.M. (1984), Analisis Data Kualitatif. Terjemahan oleh Tjetjep Rohendi Rohidi. 1992. Jakarta : Penerbit Universitas Indonesia.

Moleong, Lexy. J. (2013). Metodologi Penelitian Kualitatif. Bandung: Remaja Rosdakarya

Morissan. (2013). Teori Komunikasi:Individu Hingga Massa. Kencana: Jakarta

Mulyana, Deddy. (2002). Ilmu Komunikasi Suatu Pengantar. Bandung: PT.Remaja Rosdakarya.

Musta'in, 2010. "Teori Diri” Sebuah Tafsir Makna Simbolik (Pendekatan Teori Dramaturgi Erving

Goffman). Purwekerto: Jurnal Dakwah dan Komunikasi (Komunika) Vol. 4:269-28

Notoatmodjo, S. (2005). Promosi Kesehatan: Teori dan Aplikasi. Jakarta : Rineka Cipta

Onong, Uchjana Effendi. (2002). Spektrumr Komunikasi, Bandar Maju: Bandung

L.M., de Haes, J.C., Hoos, A.M. and Lammes, F.B. (1995). Doctor-

Patient Communication: A Review Of The Literature, Social Science and Medicin Rakhmat, J. (2002). Metode Penelitian Komunikasi. Bandung: Remaja Rosda Karya 
Vol 2 No. 2, 2019, 45-

DOI: https://doi.org/ 10.30596/persepsi.v2i2.3941

Ritzer, George, (2011). Teori Sosiologi Modern, Kencana: Jakarta , (2004). Teori Sosiologi Moder,. Gramedia:Jakarta

Ruben, Brent D, dan Lea P. Stewart. (2013). Komunikasi dan Perilaku Manusia. Jakarta: Rajawali Pers

Rudy, May T. (2005). Komunikasi dan Hubungan Masyarakat Internasional. Bandung: Refika Aditama

Sugiyono. (2007). Metode Penelitian Kuantitatif, Kualitatif, dan R\&D. Bandung: Alfabeta

Sunarto, Kamanto. (2004). Pengantar Sosiologi, Jakarta:Lembaga Penerbitan Fakultas Ekonomi Universitas Indonesia

Suneki, Sri. (2012). Paradigma Teori Dramaturgi Terhadap Kehidupan Sosial, Semarang: Jurnal Ilmiah CIVIS Vol.II: No.2

Suryo, Imam Prayogo, (2001). Metodologi Penelitian Sosial, Bandung :Remaja Rosdakarya

Widjaja. (2000). Ilmu Komunikasi Pengantar Studi, Jakarta: PT. Rineka Cipta. 